\title{
Causes of Change Orders in the Jordanian Construction Industry
}

\author{
Ala'a Alshdiefat ${ }^{1}$, Zeeshan Aziz ${ }^{2}$ \\ ${ }^{1}$ School of the Civil Engineering, Philadelphia University, Amman, Jordan \\ ${ }^{2}$ School of the Built Environment, University of Salford, Manchester, UK \\ Email: alaasms2002@gmail.com,Z.Aziz@salford.ac.uk
}

How to cite this paper: Alshdiefat, A. and Aziz, Z. (2018) Causes of Change Orders in the Jordanian Construction Industry. Journal of Building Construction and Planning Research, 6, 234-250. https://doi.org/10.4236/jbcpr.2018.64016

Received: August 28, 2018

Accepted: November 11, 2018

Published: November 14, 2018

Copyright (c) 2018 by authors and Scientific Research Publishing Inc. This work is licensed under the Creative Commons Attribution International License (CC BY 4.0).

http://creativecommons.org/licenses/by/4.0/

(c) (i) Open Access

\begin{abstract}
Change orders are common and clearly noticeable in Jordanian construction industry. Several studies have identified change orders as significant problem in Jordanian construction projects, and they mainly cause delay and cost overrun. This situation spurs the researchers for investigating the significant causes of change orders in construction projects. Thus, this paper aims to determine the main causes of change orders in the Jordanian construction private sector which responsible for significant cost overrun. Both qualitative and quantitative methods, i.e. interview and questionnaire techniques, were used to achieve this aim. Interviews were conducted as the first stage of data collection, and the results formed the basis of the questionnaire, which was distributed across the Jordanian construction sector. Content analysis was used to analyse the interview responses, while factor analysis, correlation and the Severity Index (SI) were used to analyse the questionnaire results. The findings identified three main categories of causes of change orders in private sector, namely engineering causes, causes related to the client, and circumstances of the project, with sub-causes in each category which are related to each other in significant ways and which affect each other.
\end{abstract}

\section{Keywords}

Change Orders, Construction Project, Jordan, Private Sector

\section{Introduction}

The construction industry has been facing greater challenges such as cost overrun, delay, duplication works, and change orders. Change orders have a significant influence on the successful delivery of a project, and the effectiveness and efficiency of the way changes which are controlled is a critical factor for project 
accomplishment. According to Desai et al. (2015) [1] the success of a construction project is influenced by controlling change orders and minimising their causes and impacts.

Many organisations and researchers have defined change orders in construction projects. Some definitions describe change orders as "variation orders". According to Charoenngam et al. (2003) [2], change orders are referred to as "variation orders" in Institute of Civil Engineering (ICE) conditions, also the term "variation order" is used by The International Federation of Consulting Engineering (FIDIC) [3]. A "change order" is defined as a modification to a construction contract, and the resultant impact on costs and time must be mutually agreed by the owner and the contractor (Sundar, 2013) [4]. Change orders could therefore be summarised as modifications to the contract documents through adding, modifying or deducting something in the original agreement. Change orders might be a change in the work, a change in the quality of the work or in the construction schedule, or other forms of change that affect the nature of project.

Recently, changes have become common in construction projects, according to Halwatura and Ranasinghe (2013) [5] changes occur in every construction project. This situation has spurred researchers to explore change orders critically both to determine their causes and to minimise their negative impact. The purpose of making changes varies from one project to another. Alaryan et al. (2014) [6] conclude that the top two reasons for change orders in the Kuwaiti construction industry are changes of plan and changes of the project scope by the owner. A study by Desai et al. (2015) [1] concludes that clients are responsible for the first and second most important underlying reasons for change orders in construction projects in the central Gujarat region. These changes are necessary because of the client's financial situation and a need to change to the scope of the project respectively.

Several studies have concluded that changes in construction projects are mainly attributable to design errors. According to Olsen (2012) [7], design errors are responsible for the majority of changes. Changes in a construction project might be a result of mistakes in estimation calculations. In the context of Sri Lanka, Halwatura and Ranasinghe (2013) [5] concluded that estimation errors were the major cause of change orders in road construction projects. Estimation errors could therefore be categorised as a further main cause of change orders initiated by the engineer. The quality of the contractor's work can therefore be considered an important factor in relation to change orders. Other factors in this category include poor workmanship (Al Jaloudi, 2012) [8]. Furthermore, Halwatura and Ranasinghe (2013) [5] found unforeseen conditions to be one of the top causes of change orders. Perkins (2009) [9] also concluded that different site conditions are very important cause of change orders. It can thus be concluded that different site conditions play a major part in changes in construction projects. 
The impact of these changes is broad, and affects the project parties, i.e. the client, engineer and contractor, as well as the project itself. Many researchers have concluded that the major impacts of changes are cost overruns and delays in completion. Ijaola and Iyagba (2012) [10] found that delays in completion and cost overruns are the second and third most significant impacts of change orders in Nigerian public projects. Increased costs arise for many reasons. For example, Halwatura and Ranasinghe (2013) [5] suggest that the contractor tends to charge higher rate for change items, which affects the client by increasing the overall project cost. In addition, Taylor et al. (2012) [11] conclude that change orders in the construction industry can cause frustration for project parties and result in lower performance quality.

Several researchers have founded that the Jordanian construction industry currently faces the significant challenge of reducing the costs of change orders. Thus, developing a wide understanding of the root causes of change orders is the key success factor for an effective analysis of changes. In this paper, the causes of change orders will be determined firstly through a review of relevant research in the construction industry. The causes of change orders in building projects in the Jordanian private sector have been determined through interviews with professionals from the construction sector, and the results have been used to formulate a questionnaire that gathered data from a large sample in the construction sector. Understanding the causes of change orders provided basis for minimising cost overruns arising from change in Jordan. Furthermore, this paper offers stakeholders to gain a fuller understanding of the major causes of change orders in the Jordanian construction industry, and this will prompt them to reassess their current practices in relation to change orders. Academics will be able to use the findings of this paper as a benchmark to assess the progress of the Jordanian construction industry in controlling and reducing change orders. And the international academics can use the findings of this research for making comparisons between developing countries or between developed and developing countries.

\section{Change Orders in the Jordanian Construction Industry}

A critical examination of the available literature on the Jordanian construction industry has been undertaken to develop an initial understanding of the causes and consequences of change orders in this context. Change orders are widespread and clearly noticeable in the Jordanian construction industry. Many studies have identified change orders as problem in Jordanian construction projects, and they cause delays and cost overruns. A study by Al-Momani (1996) [12] to predict the construction costs of public school buildings indicated that, by the time a project is completed, the actual cost exceeds the forecast cost by $30 \%$, whilst change orders result in an $8.3 \%$ cost overrun. Similarly, Alshdiefat (2013) [13] found that claims in construction projects have become normal and expected, with most building projects in Jordan suffering from cost overruns and 
delays in completion; according to the results of this research, change orders are the main cause of these claims. Sweis et al. (2013) [14] also found that change orders in construction projects in Jordan are considered to be one of the major factors that cause cost overruns. Such findings highlight the negative impact of change orders, and especially cost overruns, on Jordanian construction projects. This paper focus to identify the main causes of change orders in Jordanian private sector.

Between 2008 and 2012, 531 change orders were issued by the committee of the Ministry of Public Works and Housing, and this figure does not include change orders issued by the Engineer, the Secretary General and the Competent Minister (which are posts reporting to the Ministry). The total cost was 291 million Jordanian Dinars. The cost of these change orders amounts to $17 \%$ of the total cost of the projects, which is 1720 million Jordanian Dinars (Anti-Corruption Commission, 2013, cited in Alshdiefat, 2018) [15]. The literature thus views change orders in Jordanian as the main problem impacting on the cost, duration and others aspects of projects in the Jordanian construction industry. What is more, it has been found that the total costs of change orders have escalated dramatically, from $8.3 \%$ of total project costs in 1996 to more than $17 \%$ in 2013 . Such figures highlight a critical issue facing the Jordanian construction industry, which is the challenge of controlling and minimising change orders in order to improve and develop the construction sector.

The causes of change orders have been investigated by many studies in different sectors in the Jordanian construction industry. Al-Momani (2000) [16] concludes that the main causes of delays include changes initiated by designers, client requirements, the weather, site conditions, late deliveries and economic conditions. Sweis (2008) [17] found that change orders from clients are considered one of the five major factors causing delays in the Jordanian construction industry. Moreover, Sweis (2013) [18] concluded that governmental delays and design changes are the major causes of time overruns in construction projects. This implies that systematic steps must be taken to accelerate the approval process of the government (these can be achieved by reforms and modified regulations). In addition, more attention needs to be paid during the design phase to minimising the probability of change orders. Overall, client changes and design changes seem to be the major causes of change orders in Jordanian construction projects. Al Jaloudi (2012) [8] classified 49 causes of changes in four categories, namely "client", "consultant", "contractor" and "other", in water and wastewater projects in Jordan. The five main causes of changes identified are conflict between contract documents, errors and omissions in design, unforeseen problems, differing site conditions and inadequate design. The study emphasizes that the effects of changes in water and waste water projects in Jordan are great in terms of cost overruns and delays in completion. The engineer is thus seen as the major source of changes in this study, as he is considered to be responsible for three of the five major causes of change orders in such projects. According to Alshdiefat 
(2018), the Anti-Corruption Commission (2013) studied the causes of change orders in public projects. Their study indicated that change orders had led to an incredible increase in the total cost of many projects, totalling over $100 \%$ of the original cost. It was concluded that there are 13 causes of change orders, with the main ones being design errors and errors in material estimation, changes to the project scope and objectives, and a lack of communication between the project parties. These results indicate that both clients and engineers are responsible for major changes in construction projects.

Study was conducted by Assbeihat and Sweis (2015) [19] to determine the major causes of change orders in public projects, finding that the client is responsible for three of the top five primary causes of change orders. The major cause of change in public projects is the owner requiring design modifications, followed by the owner requiring additional works, and the fifth cause is "insufficient coordination among the parties by the owner". The third major cause identified in this study is "ambiguities and mistakes in specifications and drawings", while the fourth is "modifications in materials specifications". These results show that, in public projects, clients are the major source of changes in construction projects, and that they can cause changes in different ways.

Msallam et al. (2015) [20] grouped change orders in highway projects into four categories: client, consultant, contractor and "other", outlining the main causes of change orders related to each category. The main causes of change orders related to the client are changes to plans, changes in schedule and financial problems encountered by the client. Ambiguity in the design details, inadequate design, inconsistencies between contract documents and weakness in coordination are the four major causes related to consultants. Several causes are ascribed to contractors, including unfamiliarity with local conditions and lack of communication. The last category includes safety considerations, socio-cultural factors and unforeseen problems. These researchers also found that the major impacts of change orders in Jordanian highway projects are delays in completion, cost overruns and overhead expenses.

Overall, this exploration of the causes of change orders in the Jordanian construction industry concluded that the causes of changes in construction projects can be classified according to their source, i.e. the client, the engineer, the contractor and "other". It also found that change orders in the Jordanian construction industry have many negative effects, such as cost overruns and delays in completion. This paper will therefore focus on identify the main causes of change orders in building projects in the Jordanian private construction industry. The exploration has emphasised major causes, and the relationship between the causes of change orders will be explained.

\section{Methodology}

In order to identify main cause of change orders in Jordanian construction industry, the utilisation of reliable and suitable methodological research proce- 
dures are required. The procedures must be accompanied by effective data collection methods to generate useful data for analysis and achieve a meaningful research conclusion, which contributes to the existing knowledge. This research adopted a mixed method approach which integrates thematic and statistical data and combines qualitative and quantitative methods. Moreover, it allows investigation from both the deductive and inductive perspectives (Johnson et al., 2007 [21]; Jogulu and Pansiri, 2011 [22]; Östlund et al., 2011 [23]). According to Onwuegbuzie and Leech (2005) [24] and Sechrest and Sadani (1995) [25] many researchers believe using mono method is a risk to the advancement of social science, and wonder how the stakeholders can develop confidence in findings that only depend on one method. The combination of qualitative and quantitative research method is a very powerful way of gaining insights and results, as well as assisting in making inferences and drawing conclusion. The qualitative approach is suitable for understanding the complex and specific social phenomena (McMurray, 2009 [26]; Frankfort-Nachmias et al. 2015 [27]). So, it considers a suitable approach to understand and provide new information for the critical causes of change orders in Jordanian construction industry which significantly responsible for cost overrun. The quantitative approach provides objective, value-free findings which can be generalised and replicated (McMurray, 2009) [26].

Consequently, in the first stage, the research used semi-structured interviews to collect data related to the research topic. The interviews were conducted with experts in the Jordanian construction industry. The data was then analysed through content analysis, and this gave a clear picture of the major causes of change orders that are responsible for cost overruns. The qualitative results formed the basis of a questionnaire (a quantitative method).

The questionnaire is considered to be the main method of conducting a survey. A questionnaire is a relatively quick and cheap method of collecting data on a specific topic from a large number of individuals, and elicits answers to the same questions from all the individuals surveyed (Charities Evaluation Services, 2016) [28]. A questionnaire was used in the second stage of the current research, and it was designed on the basis of the literature review and the interview results. The responses to a questionnaire analysed to get the final results and conclusion. A pilot study was used for the final draft of the questionnaire before it was distributed across the Jordanian construction industry. In this exercise, the researcher asks the pilot test respondents to complete the questionnaire and provide feedback on specific questions. The pilot will show whether the questionnaire is producing information that is related to the research subject, as well as providing feedback on the questionnaire design and content. The items in the questionnaire were thus pilot-tested for clarity and appropriateness in a self-administered pre-test with five experts in the Jordanian construction sector. They were asked to complete the questionnaire and identify any complexities, unclarities or ambiguities they had experienced in responding to the questions. The pilot tests were returned with comments, and some items were eliminated and others modified in the 
light of this feedback.

Validation is essential for both qualitative and quantitative research. In qualitative research, validation depends on factors such as honesty, the richness of the data, the depth of the research, triangulation and objectivity. In this research the internal validity of the quantitative method was achieved by designing the questionnaire so that it was able to quantify what it was planned to quantify, which means that the findings represent the reality of the Jordanian construction industry in relation to change orders. External validity was achieved by using a suitable number of participants representing different stakeholders in the Jordanian construction industry. In order to validate the qualitative results, the researcher used the four evaluation criteria proposed by Hammarberg et al. (2016) [29], namely trustworthiness, credibility, applicability and consistency. Triangulation is another strategy that can improve the validity of research. Saunders et al. (2009) [30] define triangulation as a process of collecting data from multiple source to ensure that the data is consistent. Shenton (2004) [31] also suggests that triangulation addresses both credibility and confirmability (trustworthiness), while using background data to establish context will address transferability (applicability). Finally, presenting a full description of the methodology used will address dependability (consistency).

\section{Data Analysis and Research Results}

The findings provide an intriguing insight into the current situation of change orders in the Jordanian construction industry. The aim of the interviews was to explore the causes of change orders in Jordan. Participants were therefore selected on the basis of their knowledge, experience, and their management positions-all of them are projects managers-in relation to get valuable information. Construction experts from different engineering firms (design and consultancy firms), construction management firms, contractors, the Ministry of Public Works and Housing, universities, Jordanian Engineering Association (JEA) and Jordanian Construction Contractors Association (JCCA) were therefore invited to be interviewed. A diverse range of experts was invited so as to enrich the data collected and gain a deep understanding with regard to the subject, 17 interviews were conducted with these professionals to collect data which would facilitate a deep understanding of the issues. Furthermore, the second tool used for data collection, i.e. the questionnaire, was designed on the basis of the outcomes of the literature review and the interviews. The questionnaire was distributed online to people working and has experience in the Jordanian construction industry, and 155 questionnaires were completed and returned. The respondents should be involved in the construction industry as clients, engineers, first class contractors and construction managers, as well as working in regulatory bodies (the JEA and JCCA) and the government. The participants out of these categories can't participate in the questionnaire. The questionnaire sought respondents' opinions on the causes of change orders in the Jordanian construction 
industry. The questions were derived from the analysis of the interview. Respondents were asked to indicate their opinions on a Likert scale ("strongly disagree", "disagree", "neither agree nor disagree", "agree” and "strongly agree") for each question.

The interviews make it clear that change orders in the Jordanian construction industry can be caused by any of the project parties. Design errors, incomplete designs and errors in estimating quantities of materials are three main causes of change orders in the Jordanian construction sector. These arise from using unqualified staff for design or quantity surveying work, short design periods or a failure to adhere to institutional and national regulations in the design. Changes initiated by the client are also considered to be one of the main causes of change orders in the Jordanian construction industry. A client requests changes in a construction project because of changes in the scope of the project, changes in their requirements and needs, a lack of awareness or knowledge about the project, their financial circumstances, or a change in the senior management team. Critical analysis of the interviews also found that change orders in the Jordanian construction industry are frequently a result of inconsistencies between contract documents, as well as a lack of communication between the project parties. Finally, participants mentioned other causes of change orders in the Jordanian construction industry such as shortages of materials, different site conditions, or a lag between the completion of the project design and the start of construction. Table 1 below shows the causes of change orders in Jordan grouped according to the themes identified in the interviews.

The second part of data collection is questionnaire. The questionnaire was designed based of the outcomes of the literature review and the interviews. Collected questionnaires analyzed descriptively and statically by Severity Index (SI), factor analysis, and correlation test. The Severity Index (SI) was used to rank respondents' ratings of the importance of the nine causes of change orders in the Jordanian construction industry. The Severity Index is recommended by Shash

Table 1. Themes in the causes of change orders in the Jordanian construction industry (Interview results).

\begin{tabular}{l}
\hline Causes of Change Orders in the Jordanian Construction Industry \\
Design errors \\
Changes initiated by the client \\
Incomplete design \\
Estimation errors \\
Inconsistency between contract documents \\
Lack of communication between project parties \\
Shortages of materials \\
Different site conditions \\
Lag between design and construction
\end{tabular}


(1993) [32] for analyzing ordinal data where the mean and standard deviation are not suitable statistically for the overall ranking of variables. Many researchers have now adopted the Severity Index such as Ji et al. (2014) [33] and Cheng (2014) [34]. The Severity Index is illustrated in the following formula:

$$
\begin{gathered}
\text { Severity Index }(\mathrm{SI})=\sum_{i}^{5}\left(W_{i} * f_{i}\right) *(100 \% / N) \\
W_{i}=i / N
\end{gathered}
$$

where

$\mathrm{SI}=$ Severity Index; this is computed as the summation of importance ratings.

$i=$ the rating from 1 to 5 .

$W_{i}=$ the weight of each rating.

$f_{i}=$ frequency of responses for a particular rating point.

$N=$ total number of respondents rating a particular factor in the survey.

\subsection{Questionnaire Reliability}

The reliability of research has to do with getting the same results if further data is collected by using the same procedure (Saunders et al., 2009) [30]. Reliability can be estimated by Cronbach's alpha on a scale of $0 \%-100 \%$, with higher values representing more consistent answers and indicating greater reliability. The minimum acceptable value is 0.70 , which means that the answers are reliable. In this research, SPSS was used to apply Cronbach's alpha analysis to estimate the reliability of the responses in all the sections of the questionnaire, the Cronbach's alpha of causes of change orders is 0.708 . This shows that all the reliability value is over 0.70 , which means results are reliable and consistent.

\subsection{Respondents' Backgrounds}

Three questions asked participants to provide information about their background, and the responses illustrate the diversity of the sample. The majority of respondents (52) worked in engineering firms. This is followed by 40 respondents who are contractors. Construction management accounts for the smallest proportion of the sample, with only nine respondents. Sixteen are working in government, 12 in regularity bodies (the Jordanian Engineering Association (JEA), and Jordanian Construction Contractors Association (JCCA)), 11 in educational institutions, and 15 respondents are clients or developers. The highest proportion of participants (29.7\%) had between 11 and 15 years' experience in the construction industry, while only $8.4 \%$ have five years of experience or less in the sector. $27.7 \%$ have from 16 to 20 years' experience, followed by $20 \%$ who have more than 20 years, and $14.2 \%$ of the total has from 6 to 10 years' experience. Finally, the majority of participants $(82.6 \%)$ work in the private sector, while only $17.4 \%$ work in the public sector.

\subsection{Questionnaire Results}

The Severity Index was used to rank the nine causes of change orders in the Jor- 
danian construction sector. It was found that changes requested by clients are the major cause of change orders in Jordanian construction projects, and have the highest Severity Index (SI), 93.42\%, while shortages of materials has the lowest Severity Index (47.53\%), which means this does not have a major impact on the number of change orders in the Jordanian construction industry. Table 2 below shows the Severity Index values for all the causes of change orders and their ranking, as well as the median, mode, and percentage of participants' responses to the relevant statements. Figure 1 presents a radar chart for the Severity Index values of the causes of change orders. Furthermore, Table 3 presented the rank of importance of the change orders in Jordanian construction industry for each subgroup of participants based on Severity Index test. The research results as illustrated in Table 3 indicated that the main three causes of change orders in Jordanian construction projects which are responsible for significant cost overrun are; design errors, changes initiated by the client, and inconsistencies between contract documents. The results indicated a variation for the rank of importance of these causes from subgroup to another. For example, the contractors and clients believed design errors is the main cause of change orders, while engineers believed the changes initiated by the client is the main cause of change orders. In general, critical analysis of the questionnaire data found these three causes are significant causes of change orders. Furthermore, Table 3 shows all subgroups were assigned both of different site conditions and a shortage of materials as a weakness causes could lead to change orders in Jordanian construction projects.

Factor analysis is used to measure the effects of latent variables that are reflected in the observed variables, and can be considered a data reduction method (Field, 2013) [35]. The SPSS software package was used to group the nine causes of change orders, and dimension reduction (factor analysis) was run several

Table 2. Percentage of respondents, Severity Index (SI), median and mode for the causes of change orders in the Jordanian construction industry.

\begin{tabular}{|c|c|c|c|c|c|c|c|c|c|}
\hline \multirow[b]{2}{*}{ No. } & \multirow[b]{2}{*}{ Causes of Change Orders } & \multicolumn{6}{|c|}{ Percentage of Respondents } & \multirow[b]{2}{*}{ Median } & \multirow[b]{2}{*}{ Mode } \\
\hline & & $\begin{array}{l}\text { Strongly } \\
\text { Disagree }\end{array}$ & Disagree & $\begin{array}{l}\text { Neither Agree } \\
\text { or Disagree }\end{array}$ & Agree & $\begin{array}{c}\text { Strongly } \\
\text { Agree }\end{array}$ & $\begin{array}{l}\text { Severity } \\
\text { Index }\end{array}$ & & \\
\hline 1 & Changes initiated by clients & 0.7 & 0.7 & 6.6 & 15.1 & 77.0 & 93.42 & 5.00 & 5 \\
\hline 2 & Design errors & 1.3 & 1.3 & 0.6 & 33.5 & 63.2 & 91.23 & 5.00 & 5 \\
\hline 3 & Inconsistency between contract documents & 0.6 & 0.6 & 3.9 & 47.7 & 47.1 & 88.00 & 4.00 & 4 \\
\hline 4 & Lack of communication between project parties & 0 & 1.9 & 6.5 & 63.9 & 27.7 & 83.48 & 4.00 & 4 \\
\hline 5 & Incomplete design & 0.6 & 1.9 & 27.1 & 59.4 & 11.0 & 75.61 & 4.00 & 4 \\
\hline 6 & Estimation errors & 0.6 & 5.2 & 31.6 & 55.5 & 7.1 & 72.65 & 4.00 & 4 \\
\hline 7 & Time lag between design and construction phases & 0 & 7.1 & 38.1 & 51.6 & 3.2 & 70.19 & 4.00 & 4 \\
\hline 8 & Different site conditions & 0.6 & 16.9 & 55.2 & 26.0 & 1.3 & 62.08 & 3.00 & 3 \\
\hline 9 & Shortages of materials & 13.0 & 43.5 & 36.4 & 7.1 & 0 & 47.53 & 2.00 & 2 \\
\hline
\end{tabular}




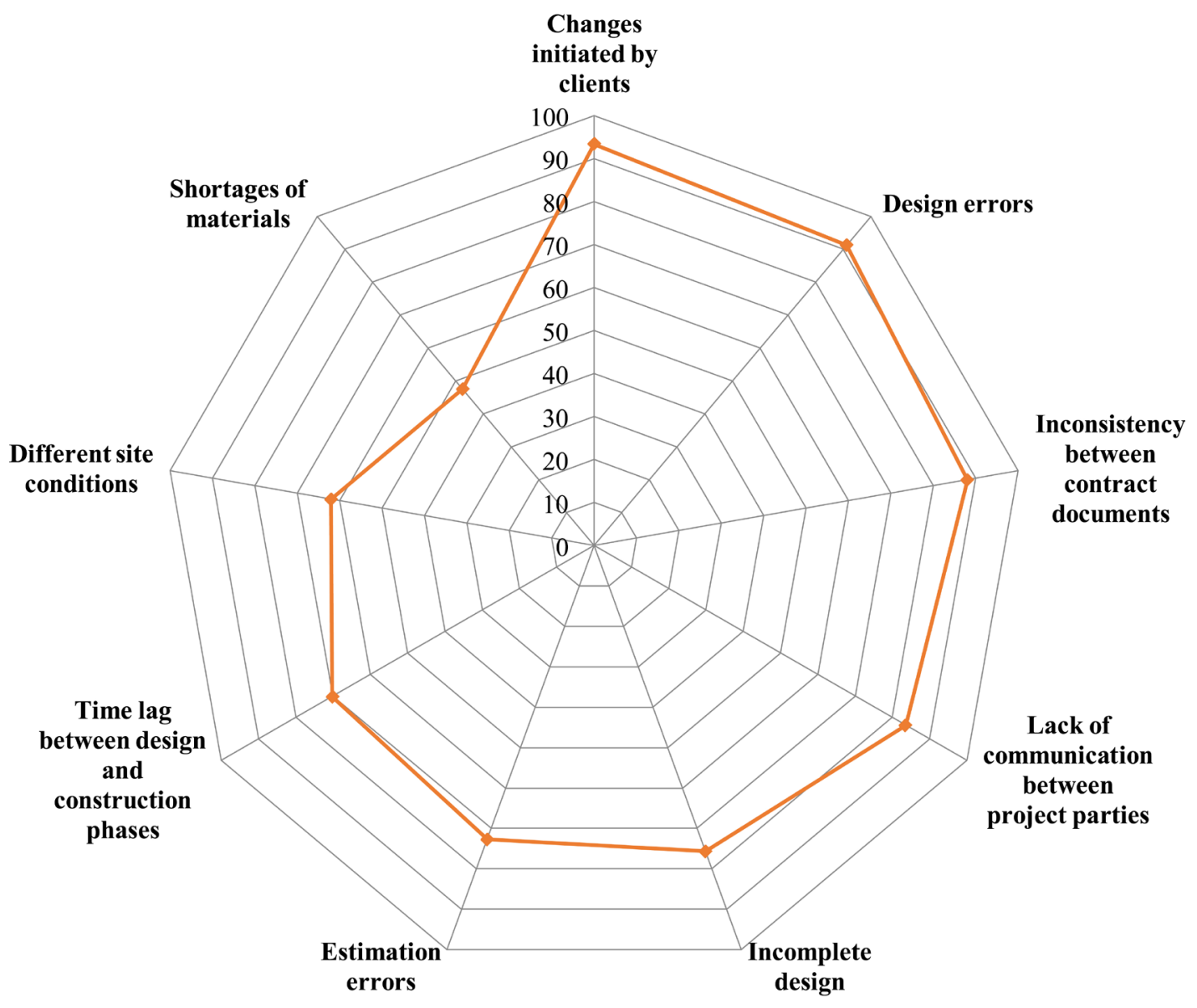

Figure 1. Severity Index for the causes of change orders in the Jordanian construction industry.

Table 3. Severity Index (SI) and the rank for the causes of change orders in the Jordanian construction industry based on participants background.

\begin{tabular}{|c|c|c|c|c|c|c|c|c|c|c|c|c|c|c|c|c|}
\hline & \multicolumn{2}{|c|}{$\begin{array}{l}\text { Engineering } \\
\text { firms }\end{array}$} & \multicolumn{2}{|c|}{ Contractors } & \multicolumn{2}{|c|}{$\begin{array}{l}\text { Clients or } \\
\text { developers }\end{array}$} & \multicolumn{2}{|c|}{$\begin{array}{l}\text { Regularity } \\
\text { bodies }\end{array}$} & \multicolumn{2}{|c|}{ Government } & \multicolumn{2}{|c|}{$\begin{array}{l}\text { Construction } \\
\text { management }\end{array}$} & \multicolumn{2}{|c|}{$\begin{array}{l}\text { Educational } \\
\text { institutions }\end{array}$} & \multicolumn{2}{|c|}{ Overall } \\
\hline & SI & Rank & SI & Rank & SI & Rank & SI & Rank & SI & Rank & SI & Rank & SI & Rank & SI & Rank \\
\hline Design errors & 83.08 & 2 & 98.50 & 1 & 93.33 & 1 & 100 & 1 & 91.25 & 2 & 91.11 & 1 & 90.91 & 2 & 91.23 & 2 \\
\hline Incomplete design & 65.77 & 6 & 82.00 & 5 & 84.00 & 4 & 80 & 4 & 81.25 & 5 & 82.22 & 4 & 69.09 & 5 & 75.61 & 5 \\
\hline $\begin{array}{l}\text { Lack of communication } \\
\text { between project parties }\end{array}$ & 81.92 & 3 & 88.50 & 4 & 90.67 & 3 & 80 & 5 & 80.00 & 6 & 75.56 & 6 & 78.18 & 4 & 83.48 & 4 \\
\hline $\begin{array}{l}\text { Time lag between design } \\
\text { and construction phases }\end{array}$ & 74.62 & 5 & 77.00 & 7 & 57.33 & 7 & 60 & 7 & 68.75 & 7 & 68.89 & 7 & 56.36 & 7 & 70.19 & 7 \\
\hline Estimation errors & 62.69 & 7 & 80.00 & 6 & 73.33 & 5 & 80 & 6 & 85.00 & 4 & 77.78 & 5 & 61.82 & 6 & 72.65 & 6 \\
\hline Changes initiated by the client & 97.65 & 1 & 97.00 & 2 & 72.00 & 6 & 100 & 2 & 86.67 & 3 & 91.11 & 2 & 94.55 & 1 & 93.42 & 1 \\
\hline $\begin{array}{l}\text { Inconsistencies between } \\
\text { contract documents }\end{array}$ & 80.00 & 4 & 91.00 & 3 & 92.00 & 2 & 100 & 3 & 95.00 & 1 & 91.11 & 3 & 83.64 & 3 & 88.00 & 3 \\
\hline Different site conditions & 61.96 & 8 & 69.74 & 8 & 50.67 & 8 & 60 & 8 & 63.75 & 8 & 60.00 & 8 & 52.73 & 8 & 62.08 & 8 \\
\hline Shortages of materials & 41.92 & 9 & 60.00 & 9 & 41.33 & 9 & 40 & 9 & 53.75 & 9 & 48.89 & 9 & 36.36 & 9 & 47.53 & 9 \\
\hline
\end{tabular}


times using absolute values of 0.50 and varimax rotation to the best reasonable causes correlated with the data. This placed the causes of change orders in the Jordanian construction industry into three main groups, as shown in Table 4, engineering causes, causes related to the circumstances of the project and those related to the client. Engineering causes include design errors, incomplete designs, estimation errors and inconsistencies between contract documents. Design errors are found to be the main cause could be explain this category with the highest load (0.823). The second group is causes related to the circumstances of the project and includes only two causes, namely different site condition and shortages of materials. Both of these have a load of over 0.80 , which means that each of them is a significant factor in relation to the circumstances of the project. The final category is causes related to the client, which contains three causes: changes initiated by the client, time lags between the design and construction phases, and lack of communication between project parties. Changes initiated by the client, with a load of 0.869 , are the most important cause in this group.

Correlation is the relationship between two variables expressed in a single number called the correlation coefficient. This has a range from +1 to -1 , and indicates the strength of the relationship and whether it is positive or negative. A correlation test was used to determine the relationship between the causes of change orders. The test used was Spearman's rho correlation test, which is a two-tailed test of statistical significance at two different levels-highly significant where $\rho<0.01$ and significant where $\rho<0.05$. The results are presented in Table 5 below.

\section{Discussion}

The analysis concluded that change orders are common in Jordanian construction projects, and have a negative impact in the form of cost overruns. The research investigated the main causes of change orders in the construction industry. These were categorized into three groups: engineering factors, client factors and the circumstances of the project.

Table 4. Factor analysis test results for the causes of change orders in Jordan.

\begin{tabular}{lccc}
\hline Latent Causes & Causes of Change Orders & \multicolumn{2}{c}{ Load } \\
\hline Engineering causes & Design errors & 0.823 & \\
& Incomplete design & 0.748 & \\
& Estimation errors & 0.807 & \\
& Inconsistencies between contract documents & 0.805 & \\
$\begin{array}{c}\text { Circumstances of } \\
\text { the project }\end{array}$ & Different site conditions & 0.804 & \\
$\begin{array}{c}\text { Causes related to } \\
\text { the client }\end{array}$ & Lack of communication between project parties & & 0.904 \\
& Time lag between design and construction phases & & 0.593 \\
& Changes initiated by the client & & 0.605 \\
\hline
\end{tabular}


Table 5. Analysis of the correlation between the causes of change orders in Jordan.

\begin{tabular}{|c|c|c|c|c|c|c|c|c|c|}
\hline $\begin{array}{l}\text { Causes of change orders in the } \\
\text { Jordanian construction industry }\end{array}$ & 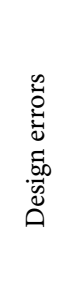 & 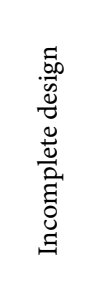 & 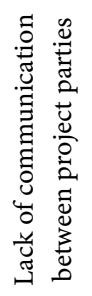 &  & 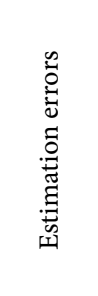 &  & 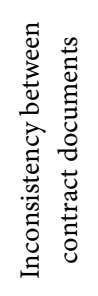 & 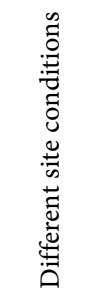 & 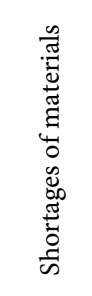 \\
\hline Design errors & 1.000 & $0.554^{\star *}$ & 0.121 & -0.031 & $0.499^{* *}$ & -0.045 & $0.576^{* *}$ & 0.080 & $0.194^{\star}$ \\
\hline Incomplete design & & 1.000 & $0.167^{*}$ & -0.109 & $0.561^{\star *}$ & $-0.239^{* *}$ & $0.492^{\star *}$ & 0.065 & $0.283^{\star *}$ \\
\hline Lack of communication between project parties & & & 1.000 & $0.219^{* *}$ & 0.066 & $0.177^{*}$ & $0.355^{\star *}$ & $0.278^{* *}$ & $0.199^{*}$ \\
\hline Time lag between design and construction phases & & & & 1.000 & -0.063 & $0.490^{* *}$ & -0.080 & $0.420^{\star *}$ & $0.373^{\star *}$ \\
\hline Estimation errors & & & & & 1.000 & $-0.270^{\star *}$ & $0.458^{* *}$ & 0.050 & $0.354^{* *}$ \\
\hline Changes initiated by clients & & & & & & 1.000 & -0.129 & $0.288^{\star *}$ & 0.118 \\
\hline Inconsistency between contract documents & & & & & & & 1.000 & 0.114 & 0.111 \\
\hline Different site conditions & & & & & & & & 1.000 & $0.620^{\star *}$ \\
\hline Shortages of materials & & & & & & & & & 1.000 \\
\hline
\end{tabular}

Firstly, the engineering category contains four causes: design errors, estimation errors, inconsistencies between contract documents and incomplete design. It was found that design errors are a significant cause of change orders in the Jordanian construction industry, and are ranked second in the opinion of the experts, with a factor analysis load of 0.823 and a Severity Index of $91.23 \%$. Design errors could occur for many reasons, including the use of unqualified staff. This matches the findings of Al Jaloudi (2012) [8] and Assbeihat and Sweis (2015) [19]. Inconsistencies between contract documents are the second main cause of change orders in the engineering category. In terms of the Severity Index $(88.0 \%)$, this is the third main cause of change orders in the Jordanian construction industry, and the factor analysis load is significantly high (0.805). There are many forms of inconsistency between contract documents; for example, there could be inconsistencies between drawings and specifications, or between different drawings. The third cause of change orders in this category is estimation errors. Although estimation errors have a quiet factor analysis load more than inconsistencies between contract documents, at $72.65 \%$ the Severity Index is much lower, and so inconsistencies must be seen as a more significant cause. This conclusion is similar to the findings of studies by Al Jaloudi (2012) [8], Assbeihat and Sweis (2015) [19] and Msallam et al. (2015) [20] which did not consider estimation errors to be a significant cause of change orders. Finally, incomplete design is the last cause of change orders related to the engineering factor. Incomplete design is ranked as the fifth main cause of change orders, and its Severity Index (SI) is $75.61 \%$. In addition, it has a high factor analysis load which is highly representative of this category (engineering) as a whole. Like inconsistencies between contract documents, incomplete designs rank more highly 
than estimation errors and have a higher Severity. What this means is clearly that there will be fewer change orders arising from estimation errors in Jordanian construction projects than those related to other causes in the engineering group. Finally, it was found that there is a significant correlation between all the causes in this group, which means a number of changes may happen consecutively.

The second category of change orders in the Jordanian construction industry is related to clients. The findings identified three causes related to clients, namely changes initiated by the client, a time lag between the design and construction phases, and lack of communication between the project parties. Changes initiated by the client are a significant cause of change orders in this category, with a factor analysis load of 0.869 , which means that they are truly representative of the category as a whole. They are also ranked as a major cause of changes in construction projects because they have a Severity Index (SI) of $93.42 \%$. This means that a large number of change orders occur because of changes in the client's requirements or needs, the client's lack of vision and awareness in relation to his project, changes in the scope of the project or the fact that the client's is experiencing financial problems. A lack of communication between parties belongs in this category because the client is responsible for selecting other project parties, and they should be able to communicate and cooperate effectively with each other in efficient manner, as well as with the client. Lack of communication is the second main cause of changes orders related to client factors in Jordanian construction projects, and it is the fourth main cause of change orders overall. That is because the factor analysis load is 0.593 , and the Severity Index (SI) is relatively high at $83.48 \%$. The research results are in keeping with Assbeihat and Sweis's (2015) [19] conclusion that insufficient coordination among the parties and with the owner ranks as the fifth main cause of change orders in public projects in Jordan. The final cause of change orders in the client factor category in the Jordanian construction industry is time lags between the design and construction phases. This period can be long or short, but in both cases it may lead to change orders. For example; if there is an extended time lag, there may be changes in the client's requirements and needs, and so he may ask for changes to be made. If it is short because of time pressure from the client, the design is likely to have errors and may not comply with local regulations. A time lag between the design and construction phases has a Severity Index (SI) of $70.19 \%$, so it is not a major cause of change orders in construction projects, and most of the experts did not mention it as a cause of change orders in the interviews. The correlation analysis showed significant relationships between all the factors related to the client, meaning that if one of these factors is present, the others might also be found.

The third group of causes of change orders in the Jordanian construction industry is the circumstances of the project. The research identified two causes in this category, shortages of materials and different site conditions. The factor 
analysis load for both of these is relatively high, showing how fully representative they are of the category as a whole. However, change orders arising from circumstances of the project circumstances are not common, and they were ranked as the last causes of change orders in Jordan. The Severity Index (SI) for shortages of materials is less than $50 \%$, and that of different site condition is $62.08 \%$, which is not significant. However, if one of them is encountered, the other is also likely to be found because they are significantly correlated.

\section{Conclusions}

Critically examined the causes of change orders in the Jordanian construction industry, the findings identify nine causes of change orders in the Jordanian construction industry, and these causes were ranked by their Severity Index. Changes relating to the client were the found to be the main cause of change orders in the Jordanian construction sector, followed by design errors, while shortages in materials was ranked bottom. The factor analysis test categorized these causes into three groups, namely engineering causes, causes related to the client and the circumstances of the project. Each of these groups includes a number of causes, as follows:

- Engineering causes: design errors, incomplete designs, estimation errors and inconsistency between contract documents;

- Causes related to the client: changes initiated by the client, lack of communication between project parties, and time lags between the design and construction phases;

- Circumstances of the project: different site conditions and shortages of materials.

The correlation test identified the relationship between the causes of change orders in each group to determine how far they influenced each other. These relationships are presented in Table 5. Finally, the future researches should be concentrated for reducing the number of change orders in construction projects through implementing information technology such as Building Information Modeling (BIM).

\section{Conflicts of Interest}

The authors declare no conflicts of interest regarding the publication of this paper.

\section{References}

[1] Desai, J., Pitroda, J. and Bhavasar, J. (2015) Analysis of Factor Affecting Change Order in Construction Industry Using RII Method. International Journal of Modern Trends in Engineering and Research, 2, 344-347.

[2] Charoenngam, C., Coquinco, S.T. and Hadikusumo, B.H.W. (2003) Web-Based Application for Managing Change Orders in Construction Projects. Construction Innovation, 3, 197-215. https://doi.org/10.1108/14714170310814936

[3] International Federation of Consulting Engineers (2010) Conditions of Contract for 
Construction for Building and Engineering Works Designed by the Employer. 1st Edition, FIDIC, Geneva.

[4] Sundar, B.S. (2013) Assessment of Cost Escalation and Overrun in Construction Projects. International Journal of Marketing and Technology, 3, 53-47.

[5] Halwatura, R.U. and Ranasinghe, N.P.N.P. (2013) Causes of Variation Orders in Road Construction Projects in Sri Lanka. ISRN Construction Engineering, 2013, 1-7. https://doi.org/10.1155/2013/381670

[6] Alaryan, A., Elbeltagi, E., Elshahat, A. and Dawood, M. (2014) Causes and Effects of Change Orders on Construction Projects in Kuwait. International Journal of Engineering Research and Applications, 1, 1-8.

[7] Olsen, D., Killingsworth, R. and Brandon, P. (2012) Change Order Causation; Who Is the Guilty Party. 48th ASC Annual International Conference Proceedings, 1, 1-9. http://ascpro.ascweb.org/chair/paper/CPGT166002012.pdf

[8] Al Jaloudi, K. (2012) Controlling of Variation Orders in Water and Wastewater Projects in Jordan. MSc Thesis, Al Isra University, Jordan.

[9] Perkins, R.A. (2009) Sources of Changes in Design-Build Contracts for a Governmental Owner. Journal of Construction Engineering and Management, 135, 588-593. https://doi.org/10.1061/(ASCE)0733-9364(2009)135:7(588)

[10] Ijaola, I.A. and Iyagba, R.O. (2012) A Comparative Study of Causes of Change Orders in Public Construction Project in Nigeria and Oman. Journal of Emerging Trends in Economics and Management Sciences, 3, 495-501.

[11] Taylor, T.R.B., Uddin, M., Goodrum, P., McCoy, A. and Shan, Y. (2012) Change Orders and Lessons Learned: Knowledge from Statistical Analyses of Engineering Change Orders on Kentucky Highway Projects. Journal of Construction Engineering and Management, 138, 1360-1369. https://doi.org/10.1061/(ASCE)CO.1943-7862.0000550

[12] Al-Momani, A.H. (1996) Construction Cost Prediction for Public School Building in Jordan. Construction Management and Economic, 14, 311-317. https://doi.org/10.1080/014461996373386

[13] Alshdiefat, A. (2013) Evaluation of Claims Management, Causes, Impacts and Resolution in Building Projects in Jordan. MSc Thesis, Al Isra University, Jordan.

[14] Sweis, G.J., Sweis, R., Rumman, M.A., Hussein, R.A. and Dahiyat, S.E. (2013) Cost Overruns in Public Construction Projects: The Case of Jordan. Journal of American Science, 9, 134-141.

[15] Alshdiefat, A. (2018) Developing an Assessment Model for the Adoption of Building Information Modelling to Reduce the Cost of Change Orders in the Jordanian Construction Industry. Unpublished PhD Thesis, University of Salford, Salford.

[16] Al-Momani, A.H. (2000) Construction Delay: A Quantitative Analysis. International Journal of Project Management, 18, 51-59. https://doi.org/10.1016/S0263-7863(98)00060-X

[17] Sweis, G., Sweis, R., Abu Hammad, A. and Shboul, A. (2008) Delays in Construction Projects: The Case of Jordan. International Journal of Project Management, 26, 665-674. https://doi.org/10.1016/j.ijproman.2007.09.009

[18] Sweis, G.J. (2013) Factors Affecting Time Overruns in Public Construction Projects: The Case of Jordan. International Journal of Business and Management, 8, 120-129. https://doi.org/10.5539/ijbm.v8n23p120

[19] Assbeihat, J.M. and Sweis, G.J. (2015) Factors Affecting Change Orders in Public Construction Projects. International Journal of Applied Science and Technology, 5, 
56-63.

[20] Msallam, M., Abojaradeh, M., Jrew, B. and Zaki, I. (2015) Controlling of Variation Orders in Highway Projects in Jordan. Journal of Engineering and Architecture, 3, 95-104. https://doi.org/10.15640/jea.v3n2a11

[21] Johnson, C. (2007) Strategic Planning for Post-Disaster Temporary Housing. Disasters, 31, 435-459. https://doi.org/10.1111/j.1467-7717.2007.01018.x

[22] Jogulu, U.D. and Pansiri, J. (2011) Mixed Methods: A Research Design for Management Doctoral Dissertations. Management Research Review, 34, 687-701. https://doi.org/10.1108/01409171111136211

[23] Östlund, U., Kidd, L., Wengström, Y. and Rowa-Dewar, N. (2011) Combining Qualitative and Quantitative Research within Mixed Method Research Designs: A Methodological Review. International Journal of Nursing Studies, 48, 369-383. https://doi.org/10.1016/j.ijnurstu.2010.10.005

[24] Onwuegbuzie, A.J. and Leech, N.L. (2005) On Becoming a Pragmatic Researcher: Importance of Combining Quantitative and Qualitative Research Methodologies. International Journal of Social Research Methodology, 8, 375-387. https://doi.org/10.1080/13645570500402447

[25] Sechrest, L. and Sadani, S. (1995) Quantitative and Qualitative Methods: Is There an Alternative? Evaluation and Program Planning, 18, 77-87. https://doi.org/10.1016/0149-7189(94)00051-X

[26] Mcmurray, D. (2009) Qualitative Research Methods. Study Guide EDU03262. Southern Cross University, Lismore.

[27] Frankfort-Nachmias, D., Nachmias, C. and DeWaard, J. (2015) Research Methods in the Social Science. 8th Edition, Worth Publishers, New York.

[28] Charities Evaluation Services (2014) Writing Better Questionnaires: Getting Better Data. Charities Evaluation Services, London.

http://www.cranfieldtrust.org/sites/default/files/files/Writing\%20better\%20question naires\%20Charities\%20Evaluation\%20Services.pdf

[29] Hammarberg, K., Kirkman, M. and De Lacey, S. (2016) Qualitative Research Methods: When to Use Them and How to Judge Them. Human Reproduction, 31, 498-501. https://doi.org/10.1093/humrep/dev334

[30] Saunders, M., Lewis, P. and Thornhill, A. (2009) Research Methods for Business Students. 5th Edition, Pearson Education, Harlow.

[31] Shenton, A. (2004) Strategies for Ensuring Trustworthiness in Qualitative Research Projects. Education for Information, 22, 63-75. https://doi.org/10.3233/EFI-2004-22201

[32] Shash, A.A. (1993) Factors Considered in Tendering Decisions by Top UK Contractors. Construction Management and Economics, 11, 111-118. https://doi.org/10.1080/01446199300000004

[33] Ji, C., Mbachu, J. and Domingo, N. (2014) Factors Influencing the Accuracy of Pre-Contract Stage Estimation of Final Contract Price in New Zealand. Supply Chain Management, 4, 51-64.

[34] Cheng, Y.M. (2014) An Exploration into Cost-Influencing Factors on Construction Projects. International Journal of Project Management, 32, 850-860. https://doi.org/10.1016/j.ijproman.2013.10.003

[35] Field, A. (2013) Discovering Statistics Using IBM SPSS Statistics. 4th Edition, Sage, London. 